\title{
Pseudohypoparathyroidism type 1C
}

INSERM

\section{Source}

INSERM. (1999). Orphanet: an online rare disease and orphan drug data base.

Pseudohypoparathyroidism type 1C. ORPHA:79444

Pseudohypoparathyroidism type 1c (PHP1C) is a rare type of pseudohypoparathyroidism (PHP; see this term) characterized by resistance to parathyroid hormone (PTH) and other hormones, which manifests with hypocalcemia, hyperphosphatemia and elevated PTH levels, a constellation of clinical features collectively termed Albright's hereditary osteodystrophy (AHO; see this term), but normal activity of the stimulatory protein $\mathrm{G}$ (Gs alpha). 